\title{
The effect of target postgrazing height on sward clover content, herbage yield, and dairy production from grass-white clover pasture
}

\author{
P. Phelan, ${ }^{*} \dagger^{1}$ I. A. Casey, $\dagger$ and J. Humphreys $\ddagger$ \\ *Animal and Grassland Research and Innovation Centre, Teagasc, Grange, Dunsany, Co. Meath, Ireland \\ †Department of Chemical and Life Sciences, Waterford Institute of Technology, Waterford, Ireland \\ $\ddagger$ Animal and Grassland Research and Innovation Centre, Teagasc, Moorepark, Co. Cork, Ireland
}

\begin{abstract}
White clover (Trifolium repens) is an important legume for grazed grassland that can increase the profitability and environmental sustainability of milk production. Previous experiments on mown grass-clover plots suggest that low postgrazing heights $(\mathrm{PGH})$ can increase sward clover content and herbage production. However, this has not been tested in actual strip or rotational grazing systems with dairy cows. Furthermore, lowering PGH in grass-only swards (typically perennial ryegrass without white clover) has previously been associated with reduced milk yields per cow. The objective of this experiment was to investigate the effect of PGH by dairy cows on clover content, herbage production, and milk production from strip-grazed grass-white clover swards in Ireland. Three target PGH treatments of 4,5 , and $6 \mathrm{~cm}$ were in place for entire grazing seasons (February to November) for 3 consecutive years (2007 to 2009). Each treatment had a mean of 21 Holstein-Friesian dairy cows that strip-grazed a mean annual area of 10.2 ha. Postgrazing height was measured twice a day with a rising plate meter, and cows were moved to the next strip once the target PGH was reached. Annual fertilizer nitrogen input was 90 $\mathrm{kg}$ of $\mathrm{N} /$ ha for each treatment. The PGH treatment did not significantly affect annual milk yield $(6,202 \mathrm{~kg} /$ cow), solids-corrected milk yield $(6,148 \mathrm{~kg} / \mathrm{cow})$, fat, protein, or lactose yields $(265,222$, and $289 \mathrm{~kg} / \mathrm{cow}$, respectively), cow liveweight $(592 \mathrm{~kg}$ ) or body condition score (3.01). The PGH treatment also had no significant effect on sward white clover content $(196 \mathrm{~g} / \mathrm{kg})$. However, herbage production of both grass and clover were significantly higher with the 4-cm PGH treatment compared with the 6-cm treatment. Mean annual herbage yields were 11.1, 10.2, and $9.1 \mathrm{t}$ of organic matter $(\mathrm{OM}) /$ ha for the 4-, 5-, and 6-cm PGH treatments, respectively. The lower herbage production in the 6-cm PGH treatment resulted in lower annual silage produc-
\end{abstract}

Received July 12, 2012.

Accepted November 23, 2012.

${ }^{1}$ Corresponding author: paul.phelan@teagasc.ie tion, greater housing requirements, and a substantially higher net silage deficit $(-1,917 \mathrm{~kg}$ of $\mathrm{OM} / \mathrm{cow})$ compared with the 5 - or 4 -cm treatments $(-868$ and -192 $\mathrm{kg}$ of $\mathrm{OM} / \mathrm{cow}$, respectively). Grazing to a PGH of $4 \mathrm{~cm}$ is therefore recommended for grass-white clover swards. Key words: postgrazing height, white clover, perennial ryegrass, milk yield

\section{INTRODUCTION}

White clover (Trifolium repens) facilitates biological nitrogen fixation (BNF) through its association with Rhizobium bacteria and can thereby reduce fertilizer $\mathrm{N}$ requirements of grassland for dairy production (Gylfadóttir et al., 2007; Humphreys et al., 2009; Del Prado et al., 2011). White clover is most commonly grown in association with perennial ryegrass (Lolium perenne), and increasing its content in herbage can improve sward nutritive value, herbage intake rates, and milk production per cow (Harris et al., 1998; Dewhurst et al., 2009; Kleen et al., 2011). Replacing fertilizer $\mathrm{N}$ use with white clover-based BNF can also improve economic performance at the farm level (Doyle and Bevan, 1996; Falconer et al., 2011; Humphreys et al., 2012). This is particularly so in recent years because of the large increase in fertilizer $\mathrm{N}$ price relative to milk price (World Bank, 1990-2012). White clover can also have important environmental benefits such as increased biodiversity (Power and Stout, 2011) and reduced greenhouse gas emissions (Li et al., 2011) for dairy production from grazed grassland.

One of the main challenges in achieving the above benefits from white clover is maintaining effective sward clover content $(>300 \mathrm{~g} / \mathrm{kg})$ within the sward from year to year (Frame and Laidlaw, 1998; Rochon et al., 2004). Previous experiments on mown, small-scale grass-clover plots have shown that lowering defoliation height can increase clover content and clover herbage production (Frame and Boyd, 1987; Acuña and Wilman, 1993; Phelan et al., 2009). The beneficial effect of lowering defoliation height on sward clover content is generally attributed to reduced shading of the clover growing points by grass (Thompson, 1993; Héraut-Bron 
et al., 2001; Christophe et al., 2006). As a result, low postgrazing heights (PGH) are often recommended for grass-clover swards. However, the effect of PGH on clover content in grass-clover swards has not been investigated in actual strip or rotational grazing systems for dairy production over entire grazing seasons. Furthermore, daily herbage allowance (DHA) experiments on grass-only swards have found that lower PGH can be associated with lower milk yields per cow and lower milk fat, protein, or lactose concentrations (Le Du et al., 1979; Maher et al., 2003; Curran et al., 2010).

The objectives of this experiment were to measure the effects of imposing a target PGH of 4,5 , or $6 \mathrm{~cm}$ on sward white clover content, herbage production, and milk production from grass-clover swards in a stripgrazing system with dairy cows over several grazing seasons. It was hypothesized that lowering PGH would (1) increase sward clover content, which would increase $\mathrm{BNF}$ and herbage production, but (2) also reduce milk yield per cow.

\section{MATERIALS AND METHODS}

\section{Experimental Area}

This experiment was conducted from January 2007 to December 2009 at Solohead Research Farm in Ireland $\left(52^{\circ} 51^{\prime} \mathrm{N}, 08^{\circ} 21^{\prime} \mathrm{W}, 95 \mathrm{~m}\right.$ above sea level). The soils of the farm are $90 \%$ poorly drained gleys and $10 \%$ graybrown podzolics with a depth ranging from 5 to $10 \mathrm{~m}$, overlaying Devonian sandstone. Drainage is impeded, which contributes to waterlogged conditions under high rainfall. The soil has a clay-loam texture of $36 \%$ sand and $28 \%$ clay in the A1 horizon. Soil organic matter content was $13 \%$ and soil $\mathrm{pH}$ was 6.6 before the experiment. The land has been under permanent grassland for over $50 \mathrm{yr}$ but was reseeded with perennial ryegrass between 1985 and 1995 and oversown with white clover between 2001 and 2006, as described by Humphreys et al. (2009). The botanical composition of the swards (in $\mathrm{g} / \mathrm{kg}$ of herbage DM, sampled in September 2008) was found to be predominantly perennial ryegrass (approximately $750 \mathrm{~g} / \mathrm{kg}$ ) and white clover (approximately $200 \mathrm{~g} / \mathrm{kg}$ ). Unsown species were primarily Taraxacum officinale (dandelion), Ranunculus repens (creeping buttercup), Bellis perennis (daisy), and Plantago lanceolata (ribwort plantain), which accounted for less than $50 \mathrm{~g} / \mathrm{kg}$ in total.

Soil temperature $\left({ }^{\circ} \mathrm{C}\right.$ at depth of $\left.10 \mathrm{~cm}\right)$ and rainfall amounts $(\mathrm{mm})$ were measured every $30 \mathrm{~min}$ at an automatic meteorological station on the farm (Campbell Scientific Ltd., Loughborough, UK). The experimental area was 40.8 ha in 2007 and 25.5 ha in both 2008 and 2009.

\section{Experimental Design and Grazing Management}

The experiment was a complete randomized block design consisting of 3 treatments that were target PGH of 4,5 , or $6 \mathrm{~cm}$ imposed for entire grazing seasons (February to November) over 3 consecutive years (2007 to 2009).

The experimental area was divided into 6 sections according to soil type and drainage status in January 2007. One paddock from each section was randomly assigned to PGH treatment and remained under that treatment until the end of the experiment in December 2009. Paddock size ranged from 1.46 to $3.30 \mathrm{ha}^{2}$ in 2007 $\left(\right.$ mean $\left.=2.27 \mathrm{ha}^{2}\right)$ and from 0.94 to $1.97 \mathrm{ha}^{2}$ in both 2008 and $2009\left(\right.$ mean $\left.=1.42 \mathrm{ha}^{2}\right)$. The total stocking rate in each treatment was 1.99 cows/ha in 2007 and 2.12 cows/ha in 2008 and 2009.

Cows were turned out to graze approximately $3 \mathrm{~d}$ after calving in mid-February and remained at pasture until they were dried off and housed full-time at the end of November. Exceptions were made when ground conditions were too wet (soil moisture $>60 \%$ ) or when herbage supply was too low, which generally occurred when herbage growth rates were below demand and pregrazing herbage mass was $<500 \mathrm{~kg}$ of DM/ha (above PGH). On such occasions, cows were housed at night and fed grass-clover silage ad libitum.

Each treatment was under strip-grazing management, with approximately 0.25 to 0.50 of each paddock allocated each time. The PGH ( $\mathrm{cm}$ above the soil surface) was measured twice per day from 50 drops with a Filips rising plate meter (www.grasstec.ie). Cows were moved to the next pasture area once the target PGH was achieved, and a back-fence was used to stop animals returning to previously grazed areas.

Slurry produced during housing was stored together and reapplied to each treatment equally during the following grazing season using regulatory protocols (European Communities Good Agricultural Practice for Protection of Water Regulations, 2009, S.I. No. 101) and an umbilical system with downward-facing splash plate. Each treatment received annual mineral fertilizer $\mathrm{N}$ input of $90 \mathrm{~kg} / \mathrm{ha}$, applied in the form of urea between February and April and as calcium ammonium nitrate (CAN) in May of each year. These were the only forms of synthetic fertilizer $\mathrm{N}$ used in this study, and no fertilizer $\mathrm{N}$ was applied during the remainder of the growing season.

Excess herbage production was identified throughout the experiment and removed for silage production. These areas were selected when herbage growth rates exceeded demand, resulting in pregrazing herbage mass $>2,000 \mathrm{~kg}$ of DM herbage (above PGH) per hectare. Such areas were generally closed from grazing between 
April 2 and May 28 (first-cut silage) or between May 23 and July 10 (second-cut silage) of each year. The proportion of the grazing area that was removed for silage production is presented in the results.

\section{Animals}

Each February, all cows on the farm were divided into 4 main groups on the basis of lactation number (1, 2,3 , and $\geq 4$ ) and then sub-divided into sub-groups of 3 on the basis of calving date. From within each subgroup, 1 cow was randomly assigned to each PGH herd. This procedure was repeated each spring.

The experiment consisted of 81 Holstein-Friesian dairy cows in 2007 (21 primiparous and 60 multiparous) and 54 (12 primiparous and 42 multiparous) in 2008 and 2009. Mean calving date was February $20(\mathrm{SD}=22 \mathrm{~d}$ ).

Cows received concentrate feed supplementation (26\% barley, $26 \%$ corn gluten, $35 \%$ beet pulp, and $12 \%$ soybean meal) at rates of approximately 3 to $5 \mathrm{~kg} /$ cow between February and April and 0 to $4 \mathrm{~kg} /$ cow between April and November, depending on herbage availability and quality (see Results). When housed over winter, the groups were fed silage ad libitum. The mean composition of fed silage $( \pm \mathrm{SD})$ throughout the experiment was $78 \mathrm{~g} / \mathrm{kg}$ ash $( \pm 13.3), 784 \mathrm{~g} / \mathrm{kg}$ OM digestibility (OMD; \pm 6.3$)$, and $122 \mathrm{~g} / \mathrm{kg} \mathrm{CP}( \pm 18.9)$.

\section{Sward Measurements}

Herbage Yields and Feeding Quality. Before each grazing event, herbage DM yield was sampled by cutting 2 to 4 random strips, each $5 \mathrm{~m}$ long and $0.55 \mathrm{~m}$ wide, using a HRH-536 lawnmower (Honda, Alpharetta, GA) set to the target PGH. Before harvesting grass-clover for silage, herbage DM yield was measured from 4 strips $(5.0 \times 1.1 \mathrm{~m})$ using an Agria auto-scythe (Etesia UK Ltd., Warwick, UK). On each occasion, the harvested herbage was bulked and weighed to determine herbage mass and a 100-g sub-sample dried for $16 \mathrm{~h}$ in a forced-draft oven at $95^{\circ} \mathrm{C}$ for $\mathrm{DM}$ content. Annual herbage yield ( $\mathrm{kg}$ of DM/ha) was calculated as the sum of herbage removed as pregrazing and presilage cuts. Growth rates for each pregrazing and presilage cut were calculated by dividing the herbage mass by the regrowth interval.

A second 100-g sub-sample of each herbage yield sample was freeze-dried and milled through a $0.2-\mathrm{mm}$ sieve before analyses for ash content $\left(550^{\circ} \mathrm{C}\right.$ muffle furnace for $12 \mathrm{~h}), \mathrm{CP}(\mathrm{N}$ content $\times 6.25$; Leco 528 auto-analyzer, Leco Corp., St. Joseph, MI), and in vitro OMD as described by Morgan et al. (1989). Herbage yield and CP results are presented as dry OM, as recommended by Elgersma and Schlepers (1996). Daily herbage allowance $(\mathrm{kg}$ of $\mathrm{OM}$ above target $\mathrm{PGH})$ was calculated retrospectively by dividing the herbage yield from pregrazing cuts by the number of days at pasture. The net energy (NE) content of pregrazing herbage was calculated from the ash content, OMD, and CP (Jarrige et al., 1986; Jarrige, 1989; O'Mara, 1996).

Silage fed to housed animals was randomly sampled ( $\mathrm{n}=88$ ) throughout the experiment by taking a grab sample of approximately $100 \mathrm{~g}$ before feeding. This was analyzed for ash, OMD, and CP using near infrared spectroscopy (model 6500, Foss-NIR System, Hillerød, Denmark).

White Clover Content in Herbage, Stolon Mass, and Biological Nitrogen Fixation. White clover content of herbage in each paddock was measured from 30 randomly distributed herbage snips (each $10 \mathrm{~cm} \times 30 \mathrm{~cm}$ ) taken to the target PGH of each treatment with electric hand shears (Accu-shears, Gardena, Ulm, Germany). This was done in April, June, and September of each year. All samples were manually separated to determine the white clover content of herbage DM.

White clover stolon mass was measured in February, May, August, and November of each year by cutting 30 random sods (each measuring $10 \times 10 \mathrm{~cm}$ ) to a depth of approximately $8 \mathrm{~cm}$ from each paddock. White clover stolons with attached roots were manually separated from the sods, washed, and analyzed for DM as described above. Annual grass and clover herbage production was calculated from the mean annual clover content of each paddock and its respective annual herbage yield. The annual BNF was estimated from annual clover herbage yield, sward age, and soil type using the model by Høgh-Jensen et al. (2004).

\section{Animal Production Measurements}

Milk Production, Liveweight, and BCS. Milking was conducted at $0730 \mathrm{~h}$ each morning and 1530 $\mathrm{h}$ each evening. Individual cow milk yield $(\mathrm{kg})$ was recorded at each milking and fat, protein, and lactose concentrations of milk from each cow were measured for a successive morning and evening milking once per week using a Milkoscan 203 analyzer (Foss Electric, Hillerød, Denmark). Yield of SCM was calculated using the equation of Tyrrell and Reid (1965). The liveweight of each cow was recorded once per week using weighing scales and the Winweigh software package (Tru-Test Ltd., Auckland, New Zealand). The BCS of each cow was recorded once every 2 wk using the methodology of Edmonson et al. (1989).

Days at Pasture and Intake Estimates. Days at pasture were recorded for each cow, with a value of 1 ascribed to each 24 -h period and a value of 0.5 ascribed 
if the animal was at pasture by day only. The amount of concentrate fed per cow was recorded at each milking (Dairymaster, Causeway, Co. Kerry, Ireland), and silage intake was estimated as silage fed to cows when housed.

Intake of grazed pasture OM by each cow was estimated as the difference between $\mathrm{NE}$ provided from silage and concentrate and that needed to meet the NE requirements for milk production, maintenance, and pregnancy (Jarrige et al., 1986; Jarrige, 1989; O’Mara, 1996). The NE content of concentrate was calculated from the constituent ingredients, and the NE content of silage was calculated from in vitro DM digestibility (DMD; O'Mara, 1996). The NE content of grazed herbage was calculated from the OMD, CP, and ash content (Jarrige et al., 1986; Jarrige, 1989; O'Mara, 1996). Cow NE requirements were calculated from milk yield, fat, protein, and lactose contents, and liveweight (Jarrige et al., 1986; Jarrige, 1989; O'Mara, 1996). Daily herbage intake (DHI; $\mathrm{kg}$ of OM) was estimated for each cow by dividing the annual amount of herbage intake by the number of days at pasture.

\section{Statistical Analyses}

All results were subjected to ANOVA using the mixed procedure in SAS (SAS Institute, 2006) with the following model:

$$
\begin{aligned}
\mathrm{X}_{\mathrm{jkl}}=\mu & +\mathrm{P}_{\mathrm{j}}+\mathrm{Y}_{1}+\mathrm{M}_{\mathrm{k}}+\mathrm{PY}_{\mathrm{jl}}+\mathrm{PM}_{\mathrm{jk}} \\
& +\mathrm{YM}_{\mathrm{lk}}+\mathrm{PYM}_{\mathrm{jkl}}+\mathrm{e}_{\mathrm{jkl}},
\end{aligned}
$$

where $X_{j k l}=$ dependent variable treatment mean, $\mu=$ overall mean, $P_{j}=$ the fixed effect of the jth $\mathrm{PGH}, \mathrm{Y}_{1}$ = the fixed effect of the lth year, $M_{k}=$ the fixed effect of the kth sampling date where applicable, and $e_{j k l}=$ residual error term. Year and sampling date (for sward clover content and clover stolon mass) were entered as repeated measures using the un@cs covariance structure, as recommended by Moser (2004). Paddock was the replicate for sward measurements and cow was the replicate for animal measurements. Year was used as the replicate for sward or animal measurements that were calculated on a herd basis for each treatment: the proportional land area removed for silage, amount of herbage produced as silage, silage surplus, and DHA.

\section{RESULTS}

\section{Meteorological Data}

Mean daily soil temperature and monthly rainfall amounts for the experimental period and the previous 10-yr means are shown in Figure 1. Mean soil temperature was $10.2,9.5$, and $9.6^{\circ} \mathrm{C}$ in 2007,2008 , and 2009 , respectively, whereas the previous $10-\mathrm{yr}$ mean was $10.9^{\circ} \mathrm{C}$ (range: 10.0 to $11.8^{\circ} \mathrm{C}$ ). Total rainfall was 990 , 1,228 , and $1,296 \mathrm{~mm}$ in 2007, 2008, and 2009 compared with the previous 10-yr mean of 1,009 mm (range 797 to $1,150 \mathrm{~mm}$ ). Therefore, 2007 showed values within the range of previous years but 2008 and 2009 were both cooler and wetter (Figure 1).

\section{Measured PGH}

The mean monthly PGH measured throughout the experiment are shown in Figure 2. The overall mean PGH over the course of the experiment were 4.1, 5.1, and $5.9 \mathrm{~cm}$ for the 4-, 5-, and 6-cm treatments respectively $(P<0.001, \mathrm{SEM}=0.02$; Figure 2$)$.

\section{Clover Persistence and Annual Grass and Clover Herbage Production}

Sward clover content and clover stolon mass per hectare are shown in Table 1. Target PGH treatment had no significant effect on sward clover content or clover stolon mass $(P>0.05)$. However, both were affected $(P<0.05)$ by year: 2009 had higher clover content but lower stolon mass than 2007 (Table 1). Clover content and stolon mass were also affected by interactions $(P$ $<0.001$ ) between year and sampling date: both tended to increase throughout the year in 2007 and 2009, but not in 2008.

Annual grass, clover, and total herbage yields are shown in Table 1. The 4-cm PGH treatment increased annual grass $(P<0.05)$, clover $(P<0.05)$, and total herbage OM yields $(P<0.001)$ compared with the 6 -cm PGH in all 3 years. Grass and total herbage OM yields were lower in 2008 and 2009 than in 2007 across all treatments $(P<0.001)$. Estimates of $\mathrm{BNF}$ were higher with the $4-\mathrm{cm}$ PGH than with the 6 -cm PGH $(P$ $<0.05$; Figure 3 ) and were not affected by year. The daily herbage growth rates throughout the experiment are shown in Figure 4. The 4-cm treatment had higher growth rates than the 6 -cm treatment $(P<0.05)$, and 2007 had higher growth rates than $2009(P<0.001)$.

\section{Pregrazing Herbage Quality}

The mean ash content, OMD, and $\mathrm{CP}$ of pregrazing herbage are shown in Table 2. Mean OMD of pregrazing herbage was not affected by PGH. However, a significant interaction was found between $\mathrm{PGH}$ and year $(P<0.01)$, in which the 6 -cm PGH had higher OMD than the 4-cm PGH in 2007 only. Moreover, CP was 

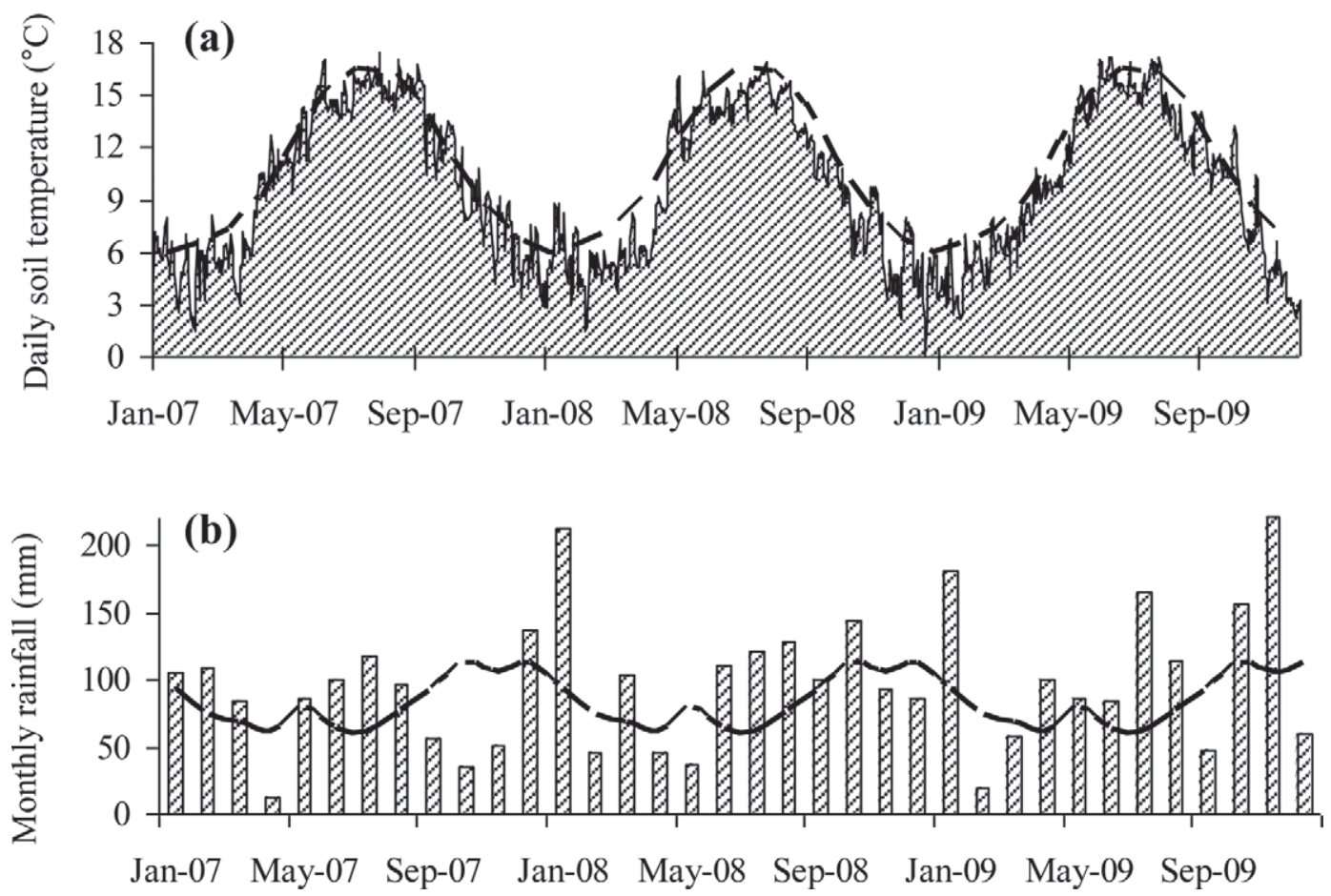

Figure 1. Mean daily soil temperature (a) and monthly rainfall amounts (b) recorded at the meteorological station at Solohead Research Farm between January 2007 and December 2009. The shaded areas show the recorded values during the experimental period, and the dashed lines show the previous 10-yr mean values (1996-2006).

lower $(P<0.05)$ and ash content higher $(P<0.001)$ with the 4-cm PGH (Table 2).

The time interval between successive grazings for each paddock (rotation length) was longer with the 4 -cm than the 6 -cm PGH $(P<0.05$; Table 2$)$. However, an interaction with year was found, in which the 5 -cm PGH had the longest intervals in 2008 only. Pregrazing herbage mass (above the target PGH) followed a similar trend and was greater with the 4-cm PGH than with the 6-cm PGH. The differences between the 4- and 5-cm PGH were affected by an interaction with year $(P<0.01)$, where the 4-cm PGH had longer intervals and higher herbage masses in 2007 and 2009 but not in 2008, when the 5-cm PGH had the highest pregrazing herbage mass (Table 2).

\section{Days at Pasture and Feed Intake per Cow}

Postgrazing height had no effect on estimated intake of grazed pasture or on the amount of concentrate fed

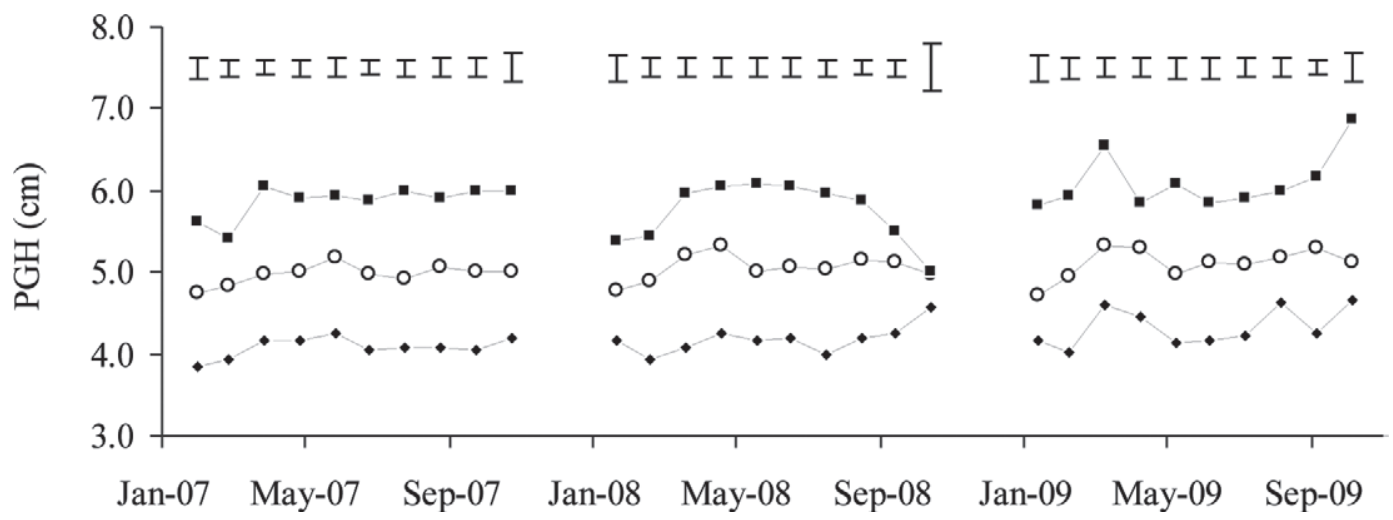

Figure 2. Effect of target postgrazing height (PGH) treatment on actual PGH measured throughout the experiment. Target PGH treatments were $4 \mathrm{~cm}(\bullet), 5 \mathrm{~cm}(\bigcirc)$, and $6 \mathrm{~cm}(\mathbf{\square})$. Error bars show the SEM of the PGH treatment, $P<0.001$. 


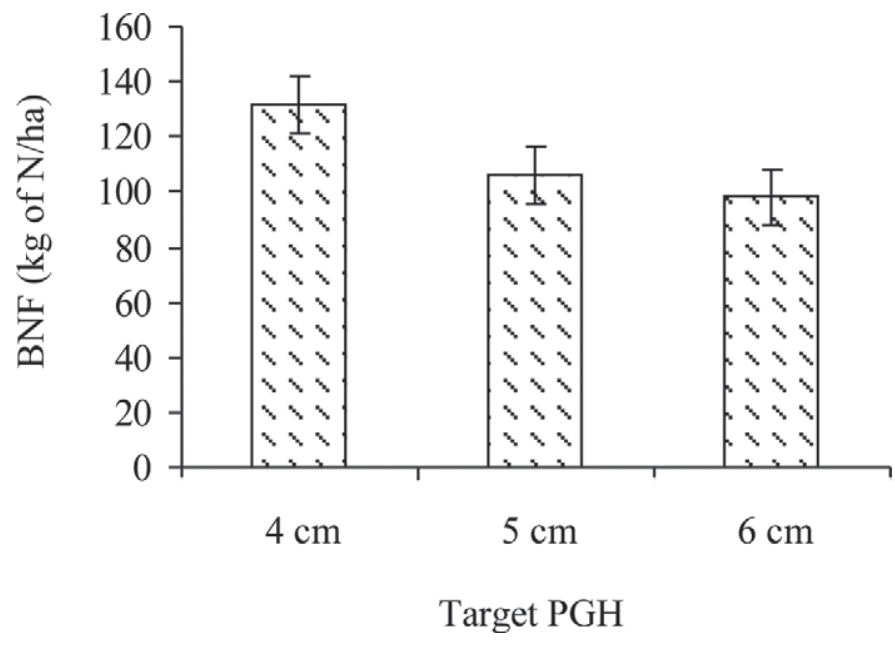

Figure 3. Effect of target postgrazing height (PGH) treatment on annual biological nitrogen fixation (BNF) estimates $(P<0.05)$. Year had no significant effect $(P>0.05)$. Error bars show the SEM of PGH treatment.

(Table 3). Estimates of DHA and DHI were also not affected by PGH (Table 3). The amount of silage fed to cows was also similar across treatments in 2007 and 2008. The weather conditions in 2008 and 2009 resulted in fewer days at pasture, less grazed grass in the cow's diet, and greater demand for silage and concentrate across treatments compared with $2007(P<0.001)$. In 2009, the 6-cm PGH had fewer days at pasture and consequently required a greater amount of silage to be fed than the other 2 treatments. This was due to management decisions to house the 6-cm PGH cows at night in April, August, and October because the lower herbage production in that system gave fewer options of dry paddocks to graze than the other treatments.

\section{Milk Production, Liveweight, and BCS}

Annual milk, SCM, fat, protein, and lactose yields were not significantly affected by PGH (Table 4). Milk fat, protein, and lactose contents were also not significantly affected (not shown). Liveweight and BCS did not differ during or at the end of each lactation (Table 4).

Differences between years were observed, with lower yields of SCM $(P<0.01)$, fat $(P<0.01)$, protein $(P$ $<0.05)$, and lactose $(P<0.01)$ in 2007 compared with 2008 (Table 4). Liveweight was higher in 2007 and 2008 than in $2009(P<0.001)$.

\section{Silage Surplus and Deficit}

The higher herbage production with the 4-cm PGH treatment resulted in a greater proportion of the grazing area being taken out for silage making $(P<0.001$;

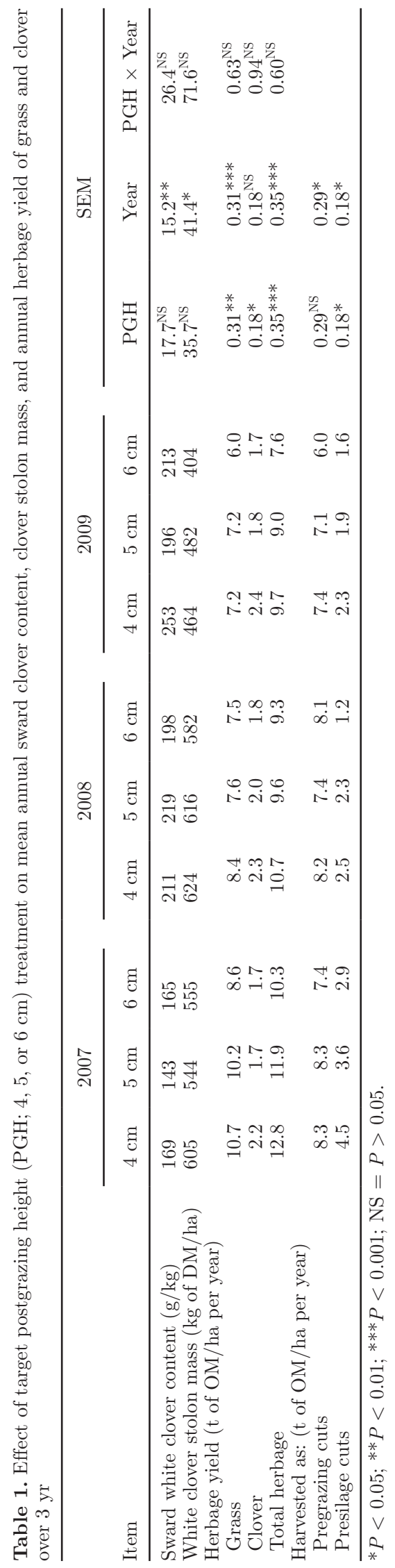

Journal of Dairy Science Vol. 96 No. 3, 2013 


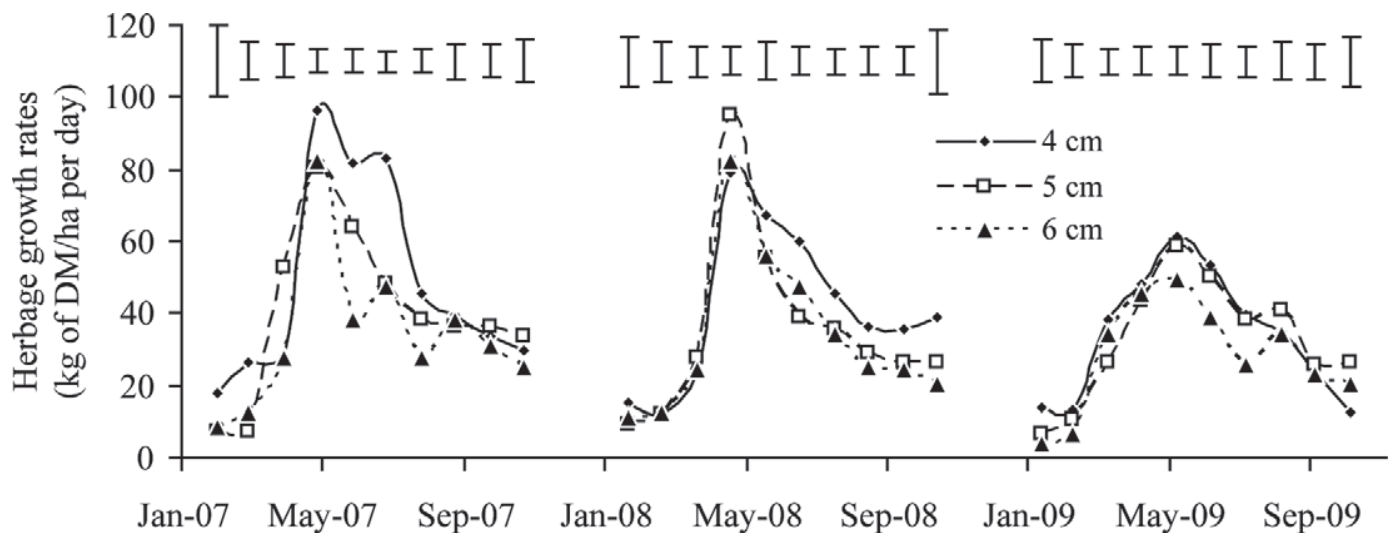

Figure 4. Effect of target postgrazing height (PGH) treatment on daily herbage growth rates throughout the experiment (PGH treatment effect: $P<0.001$ )

Table 5). As a result, the amount of silage harvested differed between all treatments, with the $4-\mathrm{cm}$ PGH producing the most and the 6 -cm PGH the least ( $P$ $<0.05$; Table 5). When combined with the greater demand for silage in the 6-cm PGH (Table 4), large differences in silage surplus or deficit were observed between treatments $(P<0.001$; Table 5$)$. Year also had a large effect $(P<0.001)$, with a surplus of silage for all 3 treatments in 2007, and a deficit in all 3 treatments in 2008 and 2009. Combined over the 3 yr of the experiment, the 4-, 5-, and 6-cm PGH resulted in net silage deficits of $-192,-868$, and $-1,917 \mathrm{~kg}$ of $\mathrm{OM} /$ cow, respectively.

\section{DISCUSSION}

\section{Grazing Management}

Postgrazing height is not an independent management variable in actual grazing systems because either a higher immediate stocking rate (as in DHA experiments) or the same immediate stocking rate grazing for a slightly longer period (as in the current experiment) is required to remove more herbage and achieve a lower PGH (from a given pregrazing herbage mass). Sward herbage mass was similar across treatments at the start of the experiment and after silage was removed. As a result, it took longer to initially graze swards down to $4 \mathrm{~cm}$ than to $6 \mathrm{~cm}$ at these times. Furthermore, the increased herbage production with the 4-cm PGH resulted in more area being removed for silage in that system (Table 5). Therefore, the results from this experiment should be interpreted as being due to the system-level effects of achieving a target PGH rather than the independent effects of PGH or defoliation height. As this is representative of on-farm conditions where the interrelatedness of grazing management factors is unavoidable, the results and outcomes are relevant for commercial farms.

\section{Clover Content and Herbage Yields}

Previous experiments on mown plots found that sward clover content, clover stolon mass, clover herbage yield, and BNF all increased in response to lowering defoliation height, with little or no effect on grass herbage yield (Frame and Boyd, 1987; Acuña and Wilman, 1993; Schils and Sikkema, 2001). Across these previous experiments, each 1-cm reduction in cutting height increased annual clover yield by 0.17 to $0.53 \mathrm{t}$ of DM/ ha and annual total herbage yield by 0.26 to $0.51 \mathrm{t}$ of $\mathrm{DM} / \mathrm{ha}$, with generally linear responses to defoliation height. In comparison, each 1-cm reduction in PGH in the current experiment increased annual clover yield by $0.34 \mathrm{t}$ of $\mathrm{DM} / \mathrm{ha}(0.28 \mathrm{t}$ of $\mathrm{OM})$ and annual total herbage yield by $1.23 \mathrm{t}$ of $\mathrm{DM} /$ ha $(1.01 \mathrm{t}$ of $\mathrm{OM})$. Unlike the previous mown experiments, grass yield also increased, which accounts for the lack of difference in the sward clover content in this experiment.

However, large differences are inherent between grazing and mowing experiments because of the interrelatedness of management variables discussed above, animal treading (Menneer et al., 2005b), selective grazing (Rutter, 2006), and animal excretion (Bao et al., 1998; Yayato et al., 2000). Under grazing conditions, transfer of fixed-N from clover to grass can be higher (Hatch and Murray, 1994; Menneer et al., 2005a; Auerswald et al., 2010) and the competitive ability of clover lower (Edwards et al., 1996; Davies, 2001) than in mown plots, which may have accounted for the lack of differences in clover content in the current experiment. This is supported by results from grass-clover swards under continuous (or set-stocked) grazing with cattle and sheep. For example, continuous grazing ex- 
Table 2. Effect of target postgrazing height $(\mathrm{PGH}, 4,5$, or $6 \mathrm{~cm})$ treatment on herbage ash content, OM digestibility (OMD), and CP, interval length between grazings, and pregrazing herbage mass above $\mathrm{PGH}$ over $3 \mathrm{yr}$

\begin{tabular}{|c|c|c|c|c|c|c|c|c|c|c|c|c|}
\hline \multirow[b]{2}{*}{ Item } & \multicolumn{3}{|c|}{2007} & \multicolumn{3}{|c|}{2008} & \multicolumn{3}{|c|}{2009} & \multicolumn{3}{|c|}{ SEM } \\
\hline & $4 \mathrm{~cm}$ & $5 \mathrm{~cm}$ & $6 \mathrm{~cm}$ & $4 \mathrm{~cm}$ & $5 \mathrm{~cm}$ & $6 \mathrm{~cm}$ & $4 \mathrm{~cm}$ & $5 \mathrm{~cm}$ & $6 \mathrm{~cm}$ & PGH & Year & $\mathrm{PGH} \times$ Year \\
\hline Ash content ( $\mathrm{g} / \mathrm{kg}$ of $\mathrm{DM})$ & 120 & 107 & 100 & 122 & 95 & 98 & 125 & 110 & 102 & $2.86^{* * *}$ & $2.86^{\mathrm{NS}}$ & $4.94^{\mathrm{NS}}$ \\
\hline $\mathrm{OMD}(\mathrm{g} / \mathrm{kg}$ of $\mathrm{DM})$ & 811 & 819 & 829 & 821 & 816 & 817 & 819 & 829 & 816 & $2.4^{\mathrm{NS}}$ & $2.4^{\mathrm{NS}}$ & $4.2^{* *}$ \\
\hline $\mathrm{CP}(\mathrm{g} / \mathrm{kg}$ of $\mathrm{OM})$ & 206 & 221 & 232 & 195 & 195 & 204 & 202 & 206 & 201 & $3.3^{*}$ & $3.3^{* * *}$ & $5.8^{\mathrm{NS}}$ \\
\hline Interval between grazings (d) & 25.9 & 21.3 & 21.6 & 27.3 & 33.5 & 28.2 & 34.0 & 31.3 & 29.9 & $0.80^{*}$ & $0.80^{* * *}$ & $1.38^{* *}$ \\
\hline $\begin{array}{l}\text { Pregrazing herbage mass } \\
(\mathrm{kg} \text { of } \mathrm{OM} / \mathrm{ha})\end{array}$ & 1,169 & 848 & 796 & 1,058 & 1,211 & 991 & 1,045 & 945 & 835 & $32.2^{* * *}$ & $32.1^{* *}$ & $55.5^{* *}$ \\
\hline
\end{tabular}

${ }^{*} P<0.05 ; * P<0.01 ; * * * P<0.001 ; \mathrm{NS}=P>0.05$

Table 3. Effect of target postgrazing height $(\mathrm{PGH}, 4,5$, and $6 \mathrm{~cm})$ treatment on grazed pasture, silage, and concentrate intakes per cow over 3 yr

\begin{tabular}{|c|c|c|c|c|c|c|c|c|c|c|c|c|}
\hline \multirow[b]{2}{*}{ Item } & \multicolumn{3}{|c|}{2007} & \multicolumn{3}{|c|}{2008} & \multicolumn{3}{|c|}{2009} & \multicolumn{3}{|c|}{ SEM } \\
\hline & $4 \mathrm{~cm}$ & $5 \mathrm{~cm}$ & $6 \mathrm{~cm}$ & $4 \mathrm{~cm}$ & $5 \mathrm{~cm}$ & $6 \mathrm{~cm}$ & $4 \mathrm{~cm}$ & $5 \mathrm{~cm}$ & $6 \mathrm{~cm}$ & PGH & Year & $\mathrm{PGH} \times$ Year \\
\hline Days at pasture & 251 & 249 & 251 & 222 & 221 & 221 & 230 & 225 & 189 & $1.76^{* * *}$ & $1.7^{* * *}$ & $3.0^{* * *}$ \\
\hline $\mathrm{DHA}^{1}(\mathrm{~kg}$ of $\mathrm{OM} / \mathrm{cow})$ & 16.7 & 16.8 & 14.8 & 17.4 & 15.7 & 17.2 & 15.1 & 15.0 & 15.0 & $0.53^{\mathrm{NS}}$ & $0.53^{\mathrm{NS}}$ & \\
\hline Intake per cow & & & & & & & & & & & & \\
\hline Grazed pasture (kg of $\mathrm{OM})$ & 3,212 & 3,195 & 3,244 & 2,951 & 2,991 & 3,025 & 2,833 & 2,790 & 2,639 & $58.6^{\mathrm{NS}}$ & $58.4^{* * *}$ & $101.1^{\mathrm{NS}}$ \\
\hline Silage $(\mathrm{kg}$ of $\mathrm{OM})$ & 1,054 & 1,068 & 1,056 & 1,324 & 1,333 & 1,335 & 1,242 & 1,288 & 1,622 & $16.5^{\text {*** }}$ & $16.4^{* * *}$ & $28.4^{* * *}$ \\
\hline Concentrate (kg of OM) & 312 & 307 & 310 & 478 & 477 & 476 & 616 & 615 & 615 & $10.8^{\mathrm{NS}}$ & $10.7^{* * *}$ & $18.5^{\mathrm{NS}}$ \\
\hline $\mathrm{DHI}^{2}(\mathrm{~kg}$ of OM$)$ & 12.8 & 12.9 & 13.0 & 13.3 & 13.5 & 13.7 & 12.3 & 12.4 & 13.9 & $0.27^{\mathrm{NS}}$ & $0.27^{\mathrm{NS}}$ & $0.47^{\mathrm{NS}}$ \\
\hline
\end{tabular}




\begin{tabular}{|c|c|c|c|c|c|c|c|c|c|c|c|c|}
\hline \multirow[b]{2}{*}{ Item } & \multicolumn{3}{|c|}{2007} & \multicolumn{3}{|c|}{2008} & \multicolumn{3}{|c|}{2009} & \multicolumn{3}{|c|}{ SEM } \\
\hline & $4 \mathrm{~cm}$ & $5 \mathrm{~cm}$ & $6 \mathrm{~cm}$ & $4 \mathrm{~cm}$ & $5 \mathrm{~cm}$ & $6 \mathrm{~cm}$ & $4 \mathrm{~cm}$ & $5 \mathrm{~cm}$ & $6 \mathrm{~cm}$ & PGH & Year & $\mathrm{PGH} \times$ Year \\
\hline Milk yield ( $\mathrm{kg} / \mathrm{cow})$ & 5,896 & 6,008 & 6,183 & 6,375 & 6,371 & 6,452 & 6,140 & 6,174 & 6,218 & $118.2^{\mathrm{NS}}$ & $117.7^{\mathrm{NS}}$ & $203.9^{\mathrm{NS}}$ \\
\hline $\mathrm{SCM}(\mathrm{kg} / \mathrm{cow})$ & 5,746 & 5.790 & 6.032 & 6.313 & 6,377 & 6,487 & 6,196 & 6,148 & 6,242 & $111.3^{\mathrm{NS}}$ & $110.9^{* *}$ & $192.0^{\mathrm{NS}}$ \\
\hline Fat $(\mathrm{g} / \mathrm{kg})$ & 247 & 247 & 257 & 271 & 274 & 280 & 271 & 266 & 273 & $5.2^{\mathrm{NS}}$ & $5.1^{* *}$ & $8.9^{\mathrm{NS}}$ \\
\hline Protein $(\mathrm{g} / \mathrm{kg})$ & 210 & 216 & 225 & 227 & 230 & 235 & 220 & 218 & 220 & $4.2^{\mathrm{NS}}$ & $4.1^{*}$ & $7.2^{\mathrm{NS}}$ \\
\hline Lactose $(\mathrm{g} / \mathrm{kg})$ & 270 & 272 & 283 & 300 & 301 & 303 & 288 & 291 & 291 & $5.4^{\mathrm{NS}}$ & $5.4^{* *}$ & $9.3^{\mathrm{NS}}$ \\
\hline Mean LW (kg/cow) & 595 & 608 & 612 & 599 & 602 & 600 & 555 & 574 & 586 & $8.1^{\mathrm{NS}}$ & $8.2^{* *}$ & $14.1^{\mathrm{NS}}$ \\
\hline $\mathrm{LW}$ at end of lactation $(\mathrm{kg} / \mathrm{cow})$ & 627 & 638 & 622 & 652 & 656 & 644 & 584 & 609 & 610 & $8.9^{\mathrm{NS}}$ & $8.9^{* *}$ & $15.4^{\mathrm{NS}}$ \\
\hline Mean BCS & 2.94 & 3.00 & 3.01 & 3.00 & 3.00 & 3.02 & 2.99 & 3.08 & 3.05 & $0.023^{\mathrm{NS}}$ & $0.023^{\text {NS }}$ & $0.040^{\mathrm{NS}}$ \\
\hline BCS at end of lactation & 2.89 & 2.98 & 2.94 & 3.00 & 3.03 & 3.01 & 2.93 & 3.06 & 3.01 & $0.032^{\mathrm{NS}}$ & $0.031^{\mathrm{NS}}$ & $0.054^{\mathrm{NS}}$ \\
\hline DIM & 288 & 286 & 287 & 299 & 295 & 297 & 286 & 289 & 288 & $2.7^{\mathrm{NS}}$ & $2.7^{*}$ & $4.7^{\mathrm{NS}}$ \\
\hline
\end{tabular}

${ }^{*} P<0.05 ;{ }^{* *} P<0.01 ; \mathrm{NS}=P>0.05$.

Table 5. Effect of target postgrazing height $(\mathrm{PGH}, 4,5$, or $6 \mathrm{~cm})$ on the proportion of the grazing area removed for silage production, the amounts of herbage yielded either as pregrazing or presilage cuts, the amounts of silage harvested and ensiled and the end-of year silage surplus/deficit over $3 \mathrm{yr}$

\begin{tabular}{|c|c|c|c|c|c|c|c|c|c|c|c|}
\hline \multirow[b]{2}{*}{ Item } & \multicolumn{3}{|c|}{2007} & \multicolumn{3}{|c|}{2008} & \multicolumn{3}{|c|}{2009} & \multicolumn{2}{|c|}{ SEM } \\
\hline & $4 \mathrm{~cm}$ & $5 \mathrm{~cm}$ & $6 \mathrm{~cm}$ & $4 \mathrm{~cm}$ & $5 \mathrm{~cm}$ & $6 \mathrm{~cm}$ & $4 \mathrm{~cm}$ & $5 \mathrm{~cm}$ & $6 \mathrm{~cm}$ & PGH & Year \\
\hline \multicolumn{12}{|c|}{$\begin{array}{l}\text { Proportional area removed } \\
\text { from each grazing system for: }\end{array}$} \\
\hline First-cut silage (May) & 0.56 & 0.43 & 0.40 & 0.42 & 0.51 & 0.25 & 0.29 & 0.37 & 0.12 & $0.042^{\mathrm{NS}}$ & $0.042^{\mathrm{NS}}$ \\
\hline Second-cut silage (July) & 0.38 & 0.22 & 0.09 & 0.14 & 0.00 & 0.00 & 0.20 & 0.11 & 0.17 & $0.039^{\mathrm{NS}}$ & $0.039^{\mathrm{NS}}$ \\
\hline Mean & 0.47 & 0.33 & 0.25 & 0.28 & 0.26 & 0.13 & 0.25 & 0.24 & 0.15 & $0.023^{*}$ & $0.023^{*}$ \\
\hline \multicolumn{12}{|l|}{ Silage (kg of OM/ha): } \\
\hline Ensiled $^{1}$ & 3.73 & 2.94 & 2.36 & 2.08 & 1.89 & 1.01 & 1.86 & 1.50 & 1.30 & $0.145^{*}$ & $0.145^{* *}$ \\
\hline Fed & 2.09 & 2.12 & 2.09 & 2.80 & 2.82 & 2.83 & 2.63 & 2.73 & 3.43 & $0.146^{\mathrm{NS}}$ & $0.146^{*}$ \\
\hline Surplus or deficit ${ }^{2}$ & 1.32 & 0.56 & 0.07 & -0.91 & -1.10 & -1.91 & -0.91 & -1.34 & -2.22 & $0.090^{* *}$ & $0.090^{* *}$ \\
\hline
\end{tabular}

${ }^{1}$ Proportional loss during ensilage assumed to be 0.25 (McGechan, 1989, 1990).

${ }^{2}$ Silage ensiled minus silage fed.

$* P<0.05 ; * * P<0.01 ; \mathrm{NS}=P>0.05$. 
periments with sheep and cattle have found that lowering grazing height can increase (Laidlaw et al., 1995), reduce (Gibb and Baker, 1989), or have no effect (Del Pozo et al., 1996) on sward clover content. However, the continuous grazing in the above examples allowed animals to have unrestricted access to the entire grazing area. The current experiment expands this work to PGH in strip-grazing systems with dairy cows and shows that lowering the target PGH from 6 to $4 \mathrm{~cm}$ can increase both grass and clover herbage yields, although the proportion of white clover in the sward did not change.

The total annual herbage yield response to lowering PGH was large compared with the previous plot-based experiments. The BNF estimates increased by an average of $17 \mathrm{~kg} / \mathrm{ha}$ per year in response to each 1 -cm reduction in PGH. This would indicate an extremely high response rate of $59 \mathrm{~kg}$ of extra OM herbage per $\mathrm{kg}$ of fixed $\mathrm{N}$, compared with the 10 to $20 \mathrm{~kg}$ reported for fertilizer N (Keating and O'Kiely, 2000; O'Donovan et al., 2004; Sun et al., 2008). However, the BNF estimates in this experiment were based solely on clover herbage yield and did not account for any changes in the proportion of fixed- $\mathrm{N}$ in clover tissue, $\mathrm{N}$ transfer rates, or $\mathrm{N}$ accumulation rates that could have occurred under the different treatments (see model description in Høgh-Jensen et al., 2004). Lowering defoliation height can also increase grass herbage production without any source of additional $\mathrm{N}$ through increased tillering, photosynthetic efficiency, increased light penetration of the sward, and less respiration and senescence below the defoliation height (Binnie and Harrington, 1972; Parsons et al., 1988; Lee et al., 2008a, 2009). Furthermore, the longer grazing intervals and greater amount of silage harvesting associated with the lower PGH may have further increased herbage production by giving the plants more time in the high growth rate zone of the sigmoidal growth curve (Parsons and Penning, 1988; Binnie et al., 1997).

\section{Pregrazing Herbage Mass, $O M D$, and $C P$}

Lowering the target PGH in the current experiment reduced herbage OMD in 2007 and $\mathrm{CP}$ concentration throughout the experiment. Lowering PGH (by reducing DHA) has previously been associated with increases in herbage OMD and $\mathrm{CP}$ in grass-only swards (McEvoy et al., 2009, 2010; Curran et al., 2010). However, in those experiments, pregrazing herbage mass had a larger effect on OMD and CP than did PGH (both were lower at higher pregrazing herbage masses). Lowering PGH in the current experiment increased the time it took for cows to rotate through the paddocks, which consequently increased pregrazing herbage mass
(Table 3). The lower OMD and CP values of pregrazing herbage grazed to $4 \mathrm{~cm}$ in the current experiment could therefore be attributed to the higher pregrazing herbage mass associated with that treatment.

\section{Milk Yields}

The current experiment found no effect of PGH on milk yield per cow or milk composition. This contrasts with previous experiments on grass-only swards (primarily perennial ryegrass with no clover) where herbage intake, milk yield, protein, fat or lactose concentrations per cow declined with PGH (Le Du et al., 1979; Maher et al., 2003; Curran et al., 2010). However, the current experiment used grass-clover swards. White clover can increase herbage intake compared with grass-only herbage (Bax and Schils, 1993; Harris et al., 1998; Ribeiro Filho et al., 2003). Therefore, its presence in the current experiment may have mitigated the negative effect of lowering PGH on herbage intake or milk yield that was observed in those previous experiments on grass-only swards. Another difference is that the above experiments were all DHA experiments, where pregrazing herbage mass was either measured or controlled and the PGH was a result of adjusting the immediate stocking rate. In such experiments, animal interactions at higher densities and overly restrictive DHA allocations may also be responsible for the lower herbage intakes and milk yields. This was shown by Lee et al. (2008b), who found that reducing PGH from 6 to $4 \mathrm{~cm}$ could actually increase milk yield per cow when DHA was kept similar, although the fact that there was no effect on milk solids yield (fat + protein) suggested a transient effect.

In the current experiment, DHA was not measured before grazing and PGH was implemented simply by not moving the cows to new pasture until the target PGH was achieved. This is similar to how target PGH are likely to be achieved on most commercial farms, given the time, labor, skill, and infrastructure that is required to calculate and allocate DHA. When DHA and DHI estimates were calculated retrospectively in the current experiment, no significant difference between treatments was found, which is in accordance with the lack of a difference in milk yields per cow between treatments. However, in DHA experiments, DHA is usually measured to ground level (Peyraud et al., 1996; Lee et al., 2008b) or to a common sward height (Maher et al., 2003; McEvoy et al., 2009), which was not the case in the current experiment.

All of the above experiments also began later in the year (April at the earliest) and were conducted for shorter periods (30 wk at the most). In comparison, the current experiment was conducted from initial turnout 
in February to housing in November, which is similar to the grazing season length on most Irish dairy farms (Creighton et al., 2011). The imposition of DHA or PGH treatments for short periods after animals had been housed indoors (Le Du et al., 1979; Mayne et al., 1987) or were already grazing to a common PGH (Maher et al., 2003; McEvoy et al., 2009, 2010; Curran et al., 2010) may have had a greater effect on behavior and herbage intake (and consequently milk yield) than was observed in the current experiment. Measuring the effect of PGH throughout the entire year in the current experiment also resulted in the experimental period including periods when herbage growth rates were lower than demand and supplementary feeds (silage and concentrate) were fed to cows. This could have buffered the effect that PGH would have on milk yield compared with experiments that excluded the use of supplementary feeds (Baudracco et al., 2010). However, all dairy farms in the experimental region use supplementary feeds during the year and the levels of supplementation were low compared with the national average for dairy farms $(636,880$, and $765 \mathrm{~kg}$ of $\mathrm{OM}$ cow for 2007, 2008, and 2009, respectively; National Farm Survey, 2007-2009).

\section{Implications for Grazing Management}

Achieving a target PGH of $4 \mathrm{~cm}$ increased BNF estimates and herbage production which, as stocking rate was constant across treatments, resulted in a greater proportion of the land being used for silage production compared with achieving a target PGH of $6 \mathrm{~cm}$. The weather conditions of the years in the current experiment highlight the implications of silage surplus/deficit on farms with impeded drainage. Extremely wet soil conditions can reduce herbage growth through anoxia (McFarlane et al., 2003) and treading damage by grazing animals (Greenwood and McKenzie, 2001; Nie et al., 2001; Drewry et al., 2008). This not only results in lower silage production but also increases silage demand as animals are more likely to be housed. All treatments required more housing at night during the wetter years of 2008 and 2009. However, cows on the 6 -cm PGH treatment were housed for a total of 41 and $36 \mathrm{~d}$ more than those on the 4 - and 5 -cm treatments, respectively. This occurred when the 6-cm PGH herd was housed at night during April, August, and October. Figure 4 shows the growth rates for the PGH treatments throughout the experiment. The difference between treatments in 2009 was not much greater at these times of the year than in previous years. However, overall growth rates were lower across all treatments in 2009, which exacerbated the problems of grazing on wet soil because it further limited the options of drier paddocks that could be grazed. Wet soils in this region require a flexible management approach, in which the drier paddocks are grazed when conditions are wettest. When herbage supply is lower than demand (approximately $36 \mathrm{~kg}$ of $\mathrm{OM} /$ ha per day) for long periods, as it was with the 6 -cm PGH in 2009, the ability to do this is curtailed.

Financial net margins have previously been shown to be negatively correlated with annual rainfall at Solohead Research Farm (Humphreys et al., 2012). In 2007, all treatments had a net silage surplus but the weather conditions in 2008 and 2009 cancelled this surplus and resulted in net silage deficits in all treatments by the end of the experiment. However, the cost of producing and feeding on-farm silage is approximately 2.8 to 3.2 times higher than grazed pasture on the basis of euros per energy unit provided (O'Donovan et al., 2011). Therefore, the increased herbage production with the 4-cm PGH might be more profitably exploited by increasing the stocking rate. Recent meta-analysis shows that increasing stocking rate by 1 cow/ha (minimum $=1.3$, maximum $=4.5$ ) generally reduces milk yield per cow by $8.7 \%$ but increases milk yield per hectare by $19.6 \%$ (McCarthy et al., 2011). As stocking rate might be better defined by changes in feed availability and requirements (Holmes et al., 2002; McCarthy et al., 2011), increasing stocking rate in response to the greater herbage production that was achieved with the 4-cm PGH treatment would be logical. However, increasing stocking rate would essentially reduce DHA, with the reductions in DHI and milk production per cow, as discussed previously, more likely to occur. Furthermore, it is not necessarily just lowering the PGH that resulted in increased herbage yield, as longer regrowth intervals and a greater amount of silage cutting were also associated with that treatment. Increasing stocking rate could also increase the risk of treading damage, which could negate any increase in herbage production on soils with impeded drainage. Management strategies such as on-off grazing (Kennedy et al., 2011) and extending the grazing interval (Phelan et al., 2011) need to be used and further developed in such a scenario.

\section{CONCLUSIONS}

The hypothesis that lowering PGH from 6 to $4 \mathrm{~cm}$ would increase sward clover content and herbage production but reduce milk yield per cow in the grazing systems of this experiment was partially accepted. An increase in herbage production (as measured in pregrazing and presilage herbage yields) was observed but no increase in sward clover content or reduction in milk yield per cow. Lowering the target PGH from 6 to $4 \mathrm{~cm}$ 
was associated with longer herbage regrowth intervals, higher herbage yields of both grass and clover, and higher silage production. Milk production, liveweight, and BCS in Holstein-Friesian dairy cows were not affected by PGH in this experiment. A target PGH of 4 $\mathrm{cm}$ is therefore recommended for grass-clover swards under grazing systems similar to the ones described because it increased herbage production without negatively affecting animal performance. The effect of increasing stocking rate while lowering PGH on herbage and animal production from grass-clover swards needs to be investigated.

\section{ACKNOWLEDGMENTS}

Funding for this study was provided by the Research Stimulus Fund Programme (RSF 07-511) and the Teagasc Walsh Fellowship Scheme. The authors gratefully acknowledge the technical input of Bill Keogh (Teagasc, Moorepark, Co. Cork, Ireland), the farm staff at Teagasc Solohead Research Farm (Tipperary, Ireland), and the laboratory staff at Teagasc, Moorepark (Co. Cork, Ireland).

\section{REFERENCES}

Acuña, P. G., and D. Wilman. 1993. Effects of cutting height on the productivity and composition of perennial ryegrass-white clover swards. J. Agric. Sci. 121:29-37.

Auerswald, K., R. Schäufele, and H. Schnyder. 2010. Paths of nitrogen transfer from Trifolium repens to non-legume plants in unfertilised pastures. Pages 752-754 in Grassland Science in Europe. Vol. 15. European Grassl. Fed., Kiel, Germany.

Bao, J., P. Giller, and G. Stakelum. 1998. Selective grazing by dairy cows in the presence of dung and the defoliation of tall grass dung patches. Anim. Sci. 66:65-74.

Baudracco, J., N. Lopez-Villalobos, C. Holmes, and K. Macdonald. 2010. Effects of stocking rate, supplementation, genotype and their interactions on grazing dairy systems: A review. N. Z. J. Agric. Res. 53:109-133.

Bax, J. A., and R. L. Schils. 1993. Animal responses to white clover. In White Clover in Europe: State of the Art. REUR Technical Series 29. Food and Agriculture Organization of the United Nations, Rome, Italy. Accessed Sept. 12, 2010. http://www.fao.org/docrep/ v2350e/v2350e00.htm.

Binnie, R. C., and F. J. Harrington. 1972. The effect of cutting height and cutting frequency on the productivity of an Italian ryegrass sward. Grass Forage Sci. 27:177-182.

Binnie, R. C., D. J. Kilpatrick, and D. M. B. Chestnutt. 1997. Effect of altering the length of the regrowth interval in early, mid- and late season on the productivity of grass swards. J. Agric. Sci. 128:303-309.

Christophe, A., B. Moulia, and C. Varlet-Grancher. 2006. Quantitative contributions of blue light and PAR to the photocontrol of plant morphogenesis in Trifolium repens (L.). J. Exp. Bot. 57:23792390 .

Creighton, P., E. Kennedy, L. Shalloo, T. M. Boland, and M. O'Donovan. 2011. A survey analysis of grassland dairy farming in Ireland, investigating grassland management, technology adoption and sward renewal. Grass Forage Sci. 66:251-264.

Curran, J., L. Delaby, E. Kennedy, J. Murphy, T. Boland, and M. O'Donovan. 2010. Sward characteristics, grass dry matter intake and milk production performance are affected by pre-grazing herbage mass and pasture allowance. Livest. Sci. 127:144-154.

Davies, A. 2001. Competition between grasses and legumes in established pastures. Pages 63-83 in Competition and Succession in Pastures. P. G. Tow and A. Lazenby, ed. CABI, Wallingford, UK. Del Pozo, M., I. A. Wright, T. E. Whyte, and P. M. Colgrove. 1996. Effects of grazing by sheep or goats on sward composition in ryegrass/white clover pasture and on subsequent performance of weaned lambs. Grass Forage Sci. 5l:142-154.

Del Prado, A., T. Misselbrook, D. Chadwick, A. Hopkins, R. J. Dewhurst, P. Davison, A. Butler, J. Schröder, and D. Scholefield. 2011. SIMSDAIRY: A modelling framework to identify sustainable dairy farms in the UK. Framework description and test for organic systems and $\mathrm{N}$ fertiliser optimisation. Sci. Total Environ. 409:3993-4009.

Dewhurst, R. J., L. Delaby, A. Moloney, T. Boland, and E. Lewis. 2009. Nutritive value of forage legumes used for grazing and silage. Ir. J. Agric. Food Res. 48:51-70.

Doyle, C. J., and K. Bevan. 1996. Economic effects of legume-based grassland systems. Pages $247-257$ in Legumes in Sustainable Farming Systems. Occas. Symp. No. 30. D. Younie, ed. Br. Grassl. Soc., Reading, UK.

Drewry, J. J., K. C. Cameron, and G. D. Buchan. 2008. Pasture yield and soil physical property responses to soil compaction from treading and grazing-A review. Aust. J. Agric. Res. 46:237-256.

Edmonson, A., I. Lean, L. Weaver, T. Farver, and G. Webster. 1989. A body condition scoring chart for Holstein dairy cows. J. Dairy Sci. 72:68-78.

Edwards, G. R., A. J. Parsons, I. A. Newman, and I. A. Wright. 1996. The spatial pattern of vegetation in cut and grazed grass/white clover pastures. Grass Forage Sci. 51:219-231.

Elgersma, A., and H. Schlepers. 1996. Nitrogen and ash concentrations in grass/clover mixtures. Pages 230-232 in Legumes in Sustainable Farming Systems. Occas. Symp. No. 30. D. Younie, ed. Br. Grassl. Soc., Reading, UK.

Falconer, L. L., G. W. Evers, and L. A. Ribera. 2011. Economic analysis of high fertilizer input, over-seeded clover and native pasture production systems in the Texas coastal bend. Pages 1-9 in South. Agric. Econ. Assoc. Annu. Mtg., Corpus Christi, TX. Accessed Sep. 20, 2012. http://EconPapers.repec.org/RePEc:ags:saea11:98740.

Frame, J., and A. G. Boyd. 1987. The effect of fertilizer nitrogen rate, white clover variety and closeness of cutting on herbage productivity from perennial ryegrass/white clover swards. Grass Forage Sci. $42: 85-96$

Frame, J., and A. Laidlaw. 1998. Managing white clover in mixed swards: Principles and practice. Revista Pastos. 28:5-33.

Gibb, M. J., and R. D. Baker. 1989. Effect of changing grazing severity on the composition of perennial ryegrass/white clover swards stocked with beef cattle. Grass Forage Sci. 44:329-334.

Greenwood, K. L., and A. B. McKenzie. 2001. Grazing effects on soil physical properties and the consequences for pastures: A review. Aust. J. Exp. Agric. 41:1231-1250.

Gylfadóttir, T., Á. Helgadóttir, and H. Høgh-Jensen. 2007. Consequences of including adapted white clover in northern European grassland: Transfer and deposition of nitrogen. Plant Soil 297:93104.

Harris, S. L., M. J. Auldist, D. A. Clark, and E. B. Jansen. 1998. Effects of white clover content in the diet on herbage intake, milk production and milk composition of New Zealand dairy cows housed indoors. J. Dairy Res. 65:389-400.

Hatch, D., and P. Murray. 1994. Transfer of nitrogen from damaged roots of white clover (Trifolium repens L.) to closely associated roots of intact perennial ryegrass (Lolium perenne L.). Plant Soil 166:181-185

Héraut-Bron, V., C. Robin, C. Varlet-Grancher, and A. Guckert. 2001. Phytochrome mediated effects on leaves of white clover: Consequences for light interception by the plant under competition for light. Ann. Bot. (Lond.) 88:737-743.

Høgh-Jensen, H., R. Loges, F. V. Jørgensen, F. P. Vinther, and E. S. Jensen. 2004. An empirical model for quantification of symbiotic 
nitrogen fixation in grass-clover mixtures. Agric. Syst. 82:181194.

Holmes, C. W., G. F. Wilson, D. D. S. Mackenzie, D. S. Flux, I. M. Brookes, and A. W. F. Davey. 2002. Milk Production from Pasture. 3rd ed. Butterworths, Wellington, New Zealand.

Humphreys, J., I. A. Casey, and A. S. Laidlaw. 2009. Comparison of milk production from clover-based and fertilizer N-based grassland on a clay-loam soil under moist temperate climatic conditions. Ir. J. Agric. Food Res. 48:71-89.

Humphreys, J., E. Mihailescu, and I. A. Casey. 2012. An economic comparison of systems of dairy production based on $\mathrm{N}$ fertilized grass and grass-white clover grassland in a moist maritime environment. Grass Forage Sci. 67:519-525.

Jarrige, R. 1989. Ruminant Nutrition: Recommended Allowances and Feed Tables. John Libbey Eurotext, Montrouge, France.

Jarrige, R., C. Demarquilly, J. P. Dulphy, A. Hoden, J. Robelin, C. Beranger, Y. Geay, M. Journet, C. Malterre, D. Micol, and M. Petit. 1986. The INRA "fill unit" system for predicting the voluntary intake of forage-based diets in ruminants: A review. J. Anim. Sci. 63:1737-1758.

Keating, T., and P. O'Kiely. 2000. Comparison of old permanent grassland, Lolium perenne and Lolium multiflorum swards grown for silage: 3 . Effects of varying fertiliser nitrogen application rate. Ir. J. Agric. Food Res. 39:35-53.

Kennedy, E., J. Curran, B. Mayes, M. McEvoy, J. P. Murphy, and M. O'Donovan. 2011. Restricting dairy cow access time to pasture in early lactation: The effects on milk production, grazing behaviour and dry matter intake. Animal 5:1805-1813.

Kleen, J., F. Taube, and M. Gierus. 2011. Agronomic performance and nutritive value of forage legumes in binary mixtures with perennial ryegrass under different defoliation systems. J. Agric. Sci. 149:73-84

Laidlaw, A. S., J. A. Withers, and L. G. Toal. 1995. The effect of surface height of swards continuously stocked with cattle on herbage production and clover content over four years. Grass Forage Sci. 50:48-54.

Le Du, Y. L. P., J. Combellas, J. Hodgeson, and R. D. Baker. 1979. Herbage intake and milk production by grazing dairy cows: 2 . The effects of level of winter feeding and daily herbage allowance. Grass Forage Sci. 34:249-260.

Lee, J. M., D. J. Donaghy, and J. R. Roche. 2008a. Effect of defoliation severity on regrowth and nutritive value of perennial ryegrass dominant swards. Agron. J. 100:308-314.

Lee, J. M., D. J. Donaghy, and J. R. Roche. 2008b. Short communication: Effect of postgrazing residual pasture height on milk production. J. Dairy Sci. 91:4307-4311.

Lee, J. M., D. J. Donaghy, P. Sathish, and J. R. Roche. 2009. Interaction between water-soluble carbohydrate reserves and defoliation severity on the regrowth of perennial ryegrass (Lolium perenne L.)dominant swards. Grass Forage Sci. 64:266-275.

Li, D., G. Lanigan, and J. Humphreys. 2011. Measured and simulated nitrous oxide emissions from ryegrass-and ryegrass/white clover-based grasslands in a moist temperate climate. PLoS ONE 6:e26176.

Maher, J., G. Stakelum, and M. Rath. 2003. Effect of daily herbage allowance on the performance of spring-calving dairy cows. Ir. J. Agric. Food Res. 42:229-241.

Mayne, C. S., R. D. Newberry, S. C. Woodcock, and R. J. Wilkins. 1987. Effect of grazing severity on grass utilization and milk production of rotationally grazed cows. Grass Forage Sci. 42:59-72.

McCarthy, B., L. Delaby, K. Pierce, F. Journot, and B. Horan. 2011. Meta-analysis of the impact of stocking rate on the productivity of pasture-based milk production systems. Animal 5:784-794.

McEvoy, M., L. Delaby, J. P. Murphy, T. M. Boland, and M. O'Donovan. 2010. Effect of herbage mass and allowance on sward characteristics, milk production, intake and rumen volatile fatty acid concentration. Grass Forage Sci. 65:335-347.

McEvoy, M., M. O’Donovan, E. Kennedy, J. P. Murphy, L. Delaby, and T. M. Boland. 2009. Effect of pregrazing herbage mass and pasture allowance on the lactation performance of Holstein-Friesian dairy cows. J. Dairy Sci. 92:414-422.
McFarlane, N., T. Ciavarella, and K. Smith. 2003. The effects of waterlogging on growth, photosynthesis and biomass allocation in perennial ryegrass (Lolium perenne L.) genotypes with contrasting root development. J. Agric. Sci. 141:241-248.

McGechan, M. 1989. A review of losses arising during conservation of grass forage: Part 1. Field losses. J. Agric. Eng. Res. 44:1-21.

McGechan, M. 1990. A review of losses arising during conservation of grass forage: Part 2. Storage losses. J. Agric. Eng. Res. 45:1-30.

Menneer, J. C., S. F. Ledgard, C. McLay, and W. Silvester. 2005a Animal treading during wet soil conditions reduces $\mathrm{N}_{2}$ fixation in mixed clover-grass pasture. Plant Soil 275:317-325.

Menneer, J. C., S. F. Ledgard, C. D. A. McLay, and W. B. Silvester. 2005b. The effects of treading by dairy cows during wet soil conditions on white clover productivity, growth and morphology in a white clover-perennial ryegrass pasture. Grass Forage Sci. 60:46-58.

Morgan, D. J., G. Stakelum, and J. O'Dwyer. 1989. Modified neutraldetergent cellulose digestibility procedure for use with the "Fibertec" system. Isr. J. Agric. Res. 28:91-92.

Moser, E. B. 2004. Repeated measures modelling with proc mixed. Pages 1-19 in SAS Users Group International Conference 29. Vol. Paper 188.29, May 9-12, 2004, Montréal, Québec, Canada.

National Farm Survey. 2007-2009. Published results. Farm Surveys Department, Teagasc, Rural Economy Research Centre, Athenry, Ireland. Accessed Sept. 6, 2011. http://www.teagasc.ie/ publications/2011/1016/NFS10.pdf.

Nie, Z. N., G. N. Ward, and A. T. Michael. 2001. Impact of pugging by dairy cows on pastures and indicators of pugging damage to pasture soil in southwestern Victoria. Aust. J. Agric. Res. 52:37-43.

O'Donovan, M., L. Delaby, G. Stakelum, and P. Dillon. 2004. Effect of autumn/spring nitrogen application date and level on dry matter production and nitrogen efficiency in perennial ryegrass swards. Ir. J. Agric. Food Res. 43:31-41.

O'Donovan, M., E. Lewis, and P. O'Kiely. 2011. Requirements of future grass based ruminant production systems in Ireland. Ir. J. Agric. Food Res. 50:1-21.

O'Mara, F. 1996. A Net Energy System for Cattle and Sheep. Department of Animal Science, Faculty of Agriculture, University College Dublin, Belfield, Dublin, Ireland.

Parsons, A., I. Johnson, and A. Harvey. 1988. Use of a model to optimize the interaction between frequency and severity of intermittent defoliation and to provide a fundamental comparison of the continuous and intermittent defoliation of grass. Grass Forage Sci. $43: 49-59$.

Parsons, A. J., and P. D. Penning. 1988. The effect of the duration of regrowth on photosynthesis, leaf death and the average rate of growth in a rotationally grazed sward. Grass Forage Sci. 43:15-27.

Peyraud, J., E. Comeron, M. Wade, and G. Lemaire. 1996. The effect of daily herbage allowance, herbage mass and animal factors upon herbage intake by grazing dairy cows. Ann. Zootech. 45:201-217.

Phelan, P., B. Keogh, I. A. Casey, and J. Humphreys. 2009. The effects of rotation length and cutting height in autumn on the productivity of a perennial ryegrass-white clover sward. Ir. J. Agric. Food Res. 48:140. (Abstr.)

Phelan, P., B. Keogh, E. Fitzgerald, I. A. Casey, and J. Humphreys. 2011. The effect of trampling by dairy cows on a rotationally grazed grass-clover sward. Page 7 in Proc. Br. Grassl. Soc. 10th Res. Conf., Belfast. British Grassland Society, Warwickshire, UK.

Power, E. F., and J. C. Stout. 2011. Organic dairy farming: Impacts on insect-flower interaction networks and pollination. J. Appl. Ecol. 48:561-569.

Ribeiro Filho, H. M. N., R. Delagarde, and J. Peyraud. 2003. Inclusion of white clover in strip-grazed perennial ryegrass swards: Herbage intake and milk yield of dairy cows at different ages of sward regrowth. Anim. Sci. 77:499-510.

Rochon, J. J., C. J. Doyle, J. M. Greef, A. Hopkins, G. Molle, M. Sitzia, D. Scholefield, and C. J. Smith. 2004. Grazing legumes in Europe: A review of their status, management, benefits, research needs and future prospects. Grass Forage Sci. 59:197-214. 
Rutter, S. M. 2006. Diet preference for grass and legumes in freeranging domestic sheep and cattle: Current theory and future application. Appl. Anim. Behav. Sci. 97:17-35.

SAS Institute. 2006. SAS User Guide. Version 9.1. SAS Institute Inc., Cary, NC.

Schils, R. L. M., and K. Sikkema. 2001. The effect of cutting height and management system on the performance of a grass/clover sward. In Lowland Grasslands of Europe: Utilization and Development. REU Technical Series 64. G. Fisher and B. Frankow-Lindberg, ed. Food and Agriculture Organization of the United Nations, Rome, Italy. Accessed July 20, 2010. http://www.fao.org/docrep/006/ AD236E/ad236e00.htm.
Sun, X., N. Luo, B. Longhurst, and J. Luo. 2008. Fertilizer nitrogen and factors affecting pasture responses. Open Agric. J. 2:35-42.

Thompson, L. 1993. The influence of the radiation environment around the node on morphogenesis and growth of white clover (Trifolium repens). Grass Forage Sci. 48:271-278.

Tyrrell, H. F., and J. Reid. 1965. Prediction of the energy value of cow's milk. J. Dairy Sci. 48:1215-1223.

World Bank. 1990-2012. Commodity trade and price trends. World Bank, Washington, DC. http://www.worldbank.org.

Yayato, M., S. Chizuru, N. Yukiko, N. Hiroki, K. Seiji, and M. Okubo. 2000. Seasonal changes of area of dung patches under strip grazing for lactating dairy cows. Grassl. Sci. 46:101-110. 